\title{
Neurotoxicity of Amyloid $\beta$-Protein: Synaptic and Network Dysfunction
}

\author{
Lennart Mucke ${ }^{1}$ and Dennis J. Selkoe ${ }^{2}$ \\ ${ }^{1}$ Gladstone Institute of Neurological Disease and University of California, San Francisco, \\ San Francisco, California 94102 \\ ${ }^{2}$ Center for Neurologic Diseases, Harvard Medical School and Brigham and Women's Hospital, \\ Boston, Massachusetts 02115 \\ Correspondence: Imucke@gladstone.ucsf.edu, dselkoe@rics.bwh.harvard.edu
}

Evidence for an ever-expanding variety of molecular mediators of amyloid $\beta$-protein neurotoxicity (membrane lipids, receptor proteins, channel proteins, second messengers and related signaling cascades, cytoskeletal proteins, inflammatory mediators, etc.) has led to the notion that the binding of hydrophobic $A \beta$ assemblies to cellular membranes triggers multiple effects affecting diverse pathways. It appears unlikely that there are only one or two cognate receptors for neurotoxic forms of $A \beta$ and also that there are just one or two assembly forms of the peptide that induce neuronal dysfunction. Rather, various soluble (diffusible) oligomers of $A \beta$ that may be in dynamic equilibrium with insoluble, fibrillar deposits (amyloid plaques) and that can bind to different components of neuronal and non-neuronal plasma membranes appear to induce complex patterns of synaptic dysfunction and network disorganization that underlie the intermittent but gradually progressive cognitive manifestations of the clinical disorder. Modern analyses of this problem utilize electrophysiology coupled with synaptic biochemistry and behavioral phenotyping of animal models to elucidate the affected circuits and assess the effects of potential therapeutic interventions.

\begin{abstract}
$A$ quarter of a century of research on amyloid $\beta$-protein $(A \beta)$ has produced a wealth of evidence that its accumulation in brain regions serving memory and cognition contributes strongly to the development of Alzheimer disease (AD). Support has come from neuropathological, genetic, biochemical, animal modeling, biomarker and, recently, therapeutic studies. There is now little doubt that the accumulation of certain forms of $A \beta$ is associated with, and probably induces, profound neuronal changes
\end{abstract}

in the brain. Cells other than neurons, including microglia, astrocytes, and the endothelial and smooth muscle cells of cerebral blood vessels, can also be altered functionally and structurally by excessive $A \beta$ levels. However, it is generally assumed that adverse effects of $A \beta$ specifically on neurons and their processes help initiate the cardinal memory and cognitive deficits that define $\mathrm{AD}$. The precise biochemical mechanisms by which various assembly forms of the peptide cause neuronal

Editors: Dennis J. Selkoe, Eckhard Mandelkow, and David M. Holtzman

Additional Perspectives on The Biology of Alzheimer Disease available at www.perspectivesinmedicine.org

Copyright (C) 2012 Cold Spring Harbor Laboratory Press; all rights reserved; doi: 10.1101/cshperspect.a006338

Cite this article as Cold Spring Harb Perspect Med 2012;2:a006338 
dysfunction and ultimately death remain to be defined.

Our focus in this chapter is the neuron and, in particular, the synapse. We emphasize that numerous synaptic and nonsynaptic neuronal changes, as well as effects on cells other than neurons, are likely to occur virtually simultaneously as the disease develops and progresses. Accordingly, it is simplistic to think about the actions of $A \beta$ on neurons - both individually and in networks-in the absence of the nonneuronal events (e.g., microgliosis, astrocytosis, microvascular injury) that could contribute to altered neuronal integrity and function secondarily. Nevertheless, we will dissect this remarkably complex scenario in a reductionist fashion, focusing first and foremost on synaptic/neuronal changes induced by $\mathrm{A} \beta$; these changes must ultimately be integrated with the effects on other cell types described in other articles in this collection.

\section{MONOMERS, OLIGOMERS, AND FIBRILS: CHANGING IDEAS ABOUT WHICH FORMS OF A $\beta$ IMPAIR NEURONAL FUNCTION AND HOW THEY DO SO}

Early versions of the amyloid cascade hypothesis of $\mathrm{AD}$ posited adverse effects of amyloid plaques on surrounding dendrites, axons and glia, based in part on the light microscopic appearance of neuritic plaques (Selkoe 1991; Hardy and Higgins 1992). However, the recognition of buffer-soluble bioactive oligomers (e.g., dimers, trimers, tetramers, dodecamers, higher oligomers) in synthetic $A \beta$ peptide preparations (Lambert et al. 1998; Bitan et al. 2001; Kayed et al. 2003), in cell culture media (Podlisny et al. 1995; Walsh et al. 2002), in amyloid precursor protein (APP) transgenic mouse brains (Kawarabayashi et al. 2001; Lesne et al. 2006; Shankar et al. 2009), and in AD brain tissue (Roher et al. 1996; McLean et al. 1999; Gong et al. 2003; Shankar et al. 2008) gave rise to the concept that the insoluble amyloid fibrils comprising the plaques might themselves be relatively inactive but serve as reservoirs of these smaller, potentially neurotoxic assemblies. Similarly, protofibrils of synthetic $A \beta$ that were thinner than classical $8 \mathrm{~nm}$ amyloid fibrils could be generated from synthetic $A \beta$ peptide under certain in vitro conditions and also induce neurotoxic effects (Harper et al. 1997; Walsh et al. 1997; Hartley et al. 1999). These biochemical findings, coupled with analogous experimental observations for other pathogenic neuronal proteins (e.g., huntingtin and $\alpha$-synuclein), have increasingly led the field to consider small, readily diffusible assemblies as principal cytotoxic forms of misfolded, self-aggregating proteins. The concept is consistent with-and emerged in part from-the demonstration that APP transgenic mice show electrophysiological, neuroanatomical and behavioral abnormalities well before the appearance of microscopically visible A $\beta$ deposits (Holcomb et al. 1999; Hsia et al. 1999; Mucke et al. 2000).

This modification of the so-called "amyloid hypothesis" based on new findings does not rule out a neurotoxic role for amyloid plaques themselves. Indeed, there is abundant evidence of neuritic alteration in the immediate vicinity of $\mathrm{AD}$ plaques, such as local distortion and curvature of normally rather straight cortical dendrites around plaques, raising the possibility of decreased efficiency of neurotransmission along them (Hyman et al. 1995). Moreover, in APP transgenic mice, array tomography has revealed a striking penumbra of excitatory synapse loss and neuritic dystrophy that is greatest immediately adjacent to a plaque and lessens in a radial fashion, becoming virtually normal approximately $30-50 \mu \mathrm{m}$ away from the plaque core edge (Spires-Jones et al. 2007; Koffie et al. 2009). Somewhat analogous findings have been described in sections of AD cortex (Serrano-Pozo et al. 2010). In mice, this penumbra is reactive with antibodies (e.g., Nab61) that are relatively specific for $A \beta$ oligomers, at least in immunochemical assays. Although it is possible that such antibodies do not retain their oligomer specificity in the complex epitope environment of brain sections, such morphological analyses suggest that plaques confer synaptic and neuritic effects in part by acting as local reservoirs of diffusible oligomers. Independent experiments in which soluble oligomers and insoluble amyloid plaque cores were 
biochemically isolated from the same $\mathrm{AD}$ cortices and assayed electrophysiologically on wildtype mouse brain slices showed that soluble oligomers potently blocked LTP, whereas washed amyloid cores did not, unless they were first dissolved in harsh solvents (e.g., formic acid) to release their constituent oligomers (Shankar et al. 2008). In this context, it has been found that lipids can convert inert $A \beta$ amyloid fibrils into neurotoxic protofibrils that can then alter learning in mice (Martins et al. 2008). Taken together, these and other experimental approaches suggest that plaques may confer local neurotoxicity because they are in equilibrium with surrounding oligomers and protofibrils. In principle, it makes biophysical sense that small oligomers would be more synaptotoxic than plaques, as the former collectively provide a much greater surface area for interaction with neurons (and glia) and their processes than do the large, nondiffusible plaques.

\section{EARLY VERSUS LATE: REFOCUSING THE INVESTIGATIVE EMPHASIS FROM FRANK NEURODEGENERATION ONTO EARLIER SYNAPTIC PERTURBATIONS CAUSED BY A $\beta$}

Most mouse lines transgenic for human (h) APP do not show overt neuronal loss, and this aspect of their phenotype is often criticized as a weakness of these models. However, it is unknown whether the loss of neurons in $\mathrm{AD}$ brains is directly caused by $A \beta$ accumulation and, even if it is, whether it takes $A \beta$ less than $2-3$ years (the typical lifetime of a mouse) to kill neurons in the human brain. The notion that hAPP transgenic mice do not undergo neurodegeneration is a misunderstanding, in that they do develop substantial neuritic dystrophy and synapse loss, which are clear signs of a neuronal degenerative process, even if counts of cell bodies are not significantly decreased. Thus, hAPP mice are good models of A $\beta$-induced synaptic dysfunction. For the following reasons, this feature alone makes them directly relevant to the human condition.

Some two decades ago, quantitative neuropathological analyses revealed strong associations between the degrees of cognitive impairment and synaptic alteration in $\mathrm{AD}$ subjects (DeKosky and Scheff 1990; Terry et al. 1991). Subsequent studies in hAPP transgenic mice and other experimental systems demonstrated that $\mathrm{A} \beta$ oligomers modulate both pre- and postsynaptic structures and functions in a dose- and assembly-dependent manner (for reviews, see Selkoe 2002; Palop and Mucke 2010). In hAPP mice, manipulations that prevent or reverse synaptic deficits also prevent or reverse cognitive impairment (e.g., McLaurin et al. 2006; Cisse et al. 2011a; Roberson et al. 2011), supporting the hypothesis that $A \beta$ causes cognitive deficits in part by interfering with synaptic functions. Because these hAPP mice have little overt neuronal loss and develop their synaptic and cognitive impairments before forming amyloid plaques, it is likely that their synaptic deficits are caused by soluble $A \beta$ assemblies rather than by plaques per se, and that these deficits reflect primary synaptotoxicity rather than secondary consequences of neuronal degeneration. Consistent with this notion, synthetic $A \beta$ oligomers and soluble $A \beta$ oligomers isolated from cell culture media or $\mathrm{AD}$ brain extracts acutely impair synaptic functions when added to hippocampal slices or slice cultures (e.g., Gong et al. 2003; Shankar et al. 2007, 2008; Li et al. 2009). Collectively, these and many other studies in the last few years have refocused the experimental approach to $A \beta$ neurotoxicity from frank cell death to more subtle structural and functional deficits of synapses and neurites.

\section{MODULATION OF SYNAPTIC TRANSMISSION BY AB: A NEGATIVE REGULATOR OF NEURONAL ACTIVITY POSTSYNAPTICALLY, BUT A POTENTIAL POSITIVE REGULATOR PRESYNAPTICALLY}

In vivo and in vitro studies have demonstrated that high levels of $A \beta$, particularly in oligomeric forms, alter glutamatergic synaptic transmission and cause synapse loss (Hsia et al. 1999; Mucke et al. 2000; Walsh et al. 2002; Kamenetz et al. 2003; Shankar et al. 2007; Li et al. 2009). On the other hand, the production of $A \beta$ and its secretion into the extracellular space are regulated in part by neuronal activity in vitro (Kamenetz et al. 2003) and in vivo (Cirrito 
et al. 2005). Increased neuronal activity enhances $\mathrm{A} \beta$ generation and blocking neuronal activity has the opposite effect (Kamenetz et al. 2003). This synaptic regulation of $A \beta$ production is mediated, at least in part, by clathrin-dependent endocytosis of surface APP at presynaptic terminals, endosomal proteolytic cleavage of APP, and A $\beta$ release at synaptic terminals (Cirrito et al. 2005). In addition, pathogenic $A \beta$ species can also be released from dendrites (Wei et al. 2010). This neuronal activity-dependent regulation of $A \beta$ secretion has been observed during pathological events, such as epileptiform activity induced by electrical stimulation (Cirrito et al. 2005), as well as during normal physiological processes, such as the sleep-wake cycle (Kang et al. 2009). Such experimental findings support the concept that APP, and its $A \beta$ fragment in particular, are part of a feedback loop controlling neuronal excitability (Kamenetz et al. 2003). In this paradigm, A $\beta$ production is enhanced by action potential-dependent synaptic activity, leading to increased levels of extracellular $A \beta$ at and near synapses and reduction of excitatory transmission postsynaptically (Fig. 1). Pathologically elevated levels of $A \beta$ would be expected to put this negative feedback regulator into overdrive, suppressing excitatory synaptic activity at the postsynaptic level. However, a caveat about some of the experimental observations just cited that underlie this model is that the investigators could not always be sure what assembly state the $A \beta$ being detected was in, that is, soluble monomers and/or soluble oligomers. Because these assemblies are likely to exist in a dynamic equilibrium, it can be difficult to assign the neurophysiological effects of $A \beta$ to a particular assembly form, depending on exactly how an experiment was conducted.

Some work suggests that $A \beta$ could also act as a positive regulator at the presynaptic level. For example, relatively small increases in endogenous $\mathrm{A} \beta$ levels $(\sim 1.5 \times)$, induced by inhibition of extracellular $A \beta$ degradation in otherwise unmanipulated wild-type neurons, enhanced the release probability of synaptic vesicles and increased neuronal activity in neuronal culture (Abramov et al. 2009). In this study, enhanced extracellular $A \beta$ increased spontaneous excitatory postsynaptic currents without significantly altering inhibitory currents. Importantly, all these effects were exclusively presynaptic and dependent on firing rates, with lower facilitation seen in neurons with higher firing rates. Thus, small increases of $A \beta$ may facilitate presynaptic glutamatergic release in neurons with low activity but not in neurons with high activity. Generally consistent with the above findings, another study reported that application of low concentrations of synthetic A $\beta 42$ (picomolar range) markedly potentiated synaptic transmission, whereas higher concentrations of $\mathrm{A} \beta 42$ (low nanomolar range) caused the expected synaptic depression (Puzzo et al. 2008). In this study, the potentiating effect of $A \beta$ did not affect postsynaptic $\mathrm{N}$-methyl D-aspartate receptor (NMDAR) and $\alpha$-amino-3-hydroxy-5-methyl-4-isoxazolepropionic acid receptor (AMPAR) currents but was dependent on $\alpha 7$-nAChR activation, suggesting a presynaptic mechanism mediated by build-up of $\mathrm{Ca}^{2+}$ in presynaptic terminals. Thus, $\mathrm{A} \beta$ may directly act on presynaptic $\alpha 7-n A C h R$ (Dineley et al. 2002) and be part of a positive feedback loop that increases presynaptic $\mathrm{Ca}^{2+}$ levels and $\mathrm{A} \beta$ secretion. Consistent with this model, blocking $\mathrm{nAChRs}$ or removing $\alpha 7-\mathrm{nAChRs}$ decreased $\mathrm{A} \beta$ secretion and blocked $A \beta$-induced facilitation (Wei et al. 2010).

It should be pointed out that the interpretation of physiological experiments examining synthetic $A \beta 42$ is difficult, because its two extra hydrophobic residues (alanine and isoleucine) give it a remarkable propensity to aggregate, even at low concentrations. Oligomers of A $\beta 42$ should have different biological properties than monomers of $A \beta 42$ given their different structures. Consequently, in vitro studies of the normal function of $A \beta$ should instead focus on the $A \beta 40$ peptide, as this is by far (tenfold) the most abundant $A \beta$ monomer under physiological conditions in young mammals. Studies that attribute normal biological functions to low levels of $A \beta 42$ must confirm these findings using $A \beta 40$.

Another emerging lesson is that $A \beta$-induced presynaptic effects depend on an optimal 
Synaptic and Network Dysfunction

A

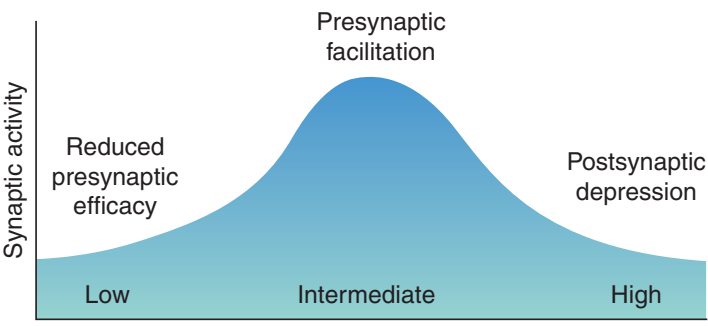

APP/A $\beta$ levels
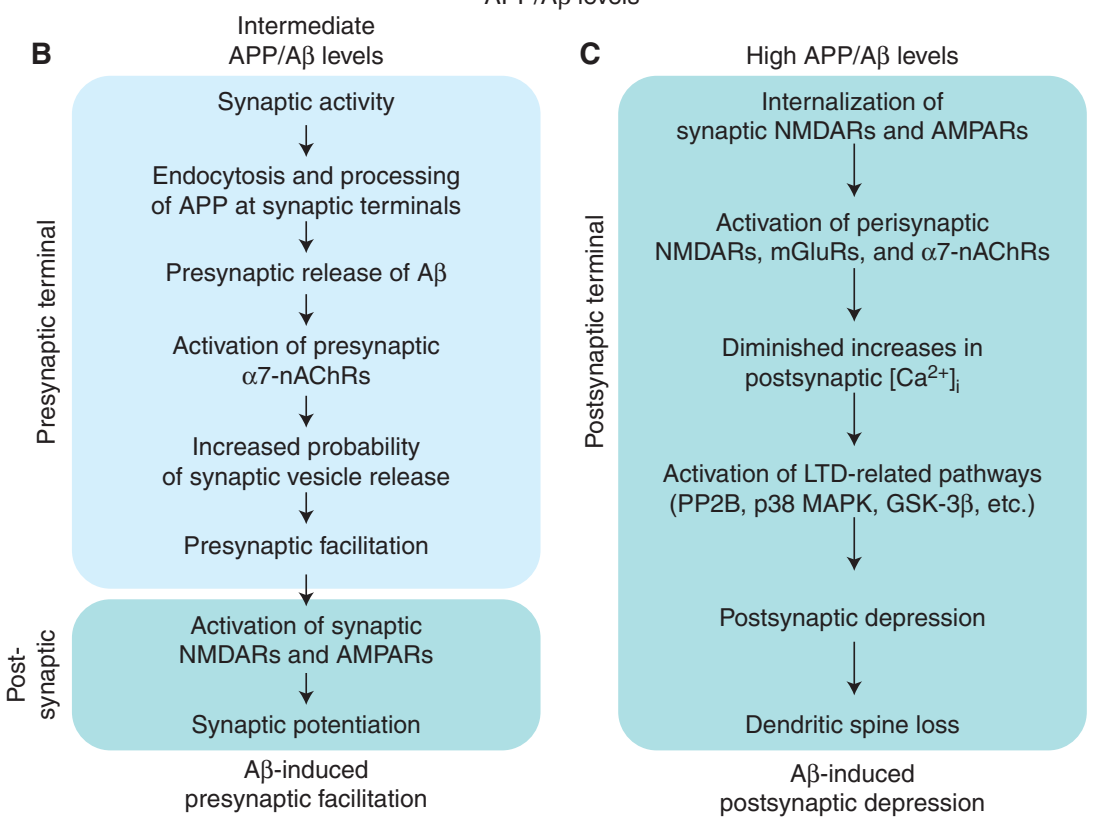

Figure 1. Presynaptic and postsynaptic regulation of synaptic transmission by amyloid $\beta$-protein $(\mathrm{A} \beta)$. (A) Hypothetical relationship between $A \beta$ level and synaptic activity. Intermediate levels of $A \beta$ enhance synaptic activity presynaptically, whereas abnormally high or low levels of $A \beta$ impair synaptic activity by inducing postsynaptic depression or reducing presynaptic efficacy, respectively. (B) Within a physiological range, small increases in $\mathrm{A} \beta$ primarily facilitate presynaptic functions, resulting in synaptic potentiation. $(C)$ At abnormally high levels, $A \beta$ enhances long-term depression (LTD)-related mechanisms, resulting in postsynaptic depression and loss of dendritic spines (modified from Palop and Mucke 2010).

$\mathrm{A} \beta$ concentration (Fig. 1), with higher or lower concentrations potentially impairing synaptic transmission (Abramov et al. 2009). A positive modulatory effect of $\mathrm{A} \beta$ on synaptic transmission is further supported indirectly by the finding that abnormally low levels of $\mathrm{A} \beta$ in mice deficient for APP (Seabrook et al. 1999), PS1 (Saura et al. 2004), or BACE1 (Laird et al. 2005) are associated with synaptic transmission deficits. Overall, these and other data suggest an apparent bell-shaped relationship between extracellular $A \beta$ and synaptic transmission in which intermediate levels of $\mathrm{A} \beta$ potentiate presynaptic terminals, low levels reduce presynaptic efficacy, and high levels depress postsynaptic transmission.

\section{Elevated Levels of $A \beta$ Impair Synaptic Transmission by Enhancing Synaptic Depression}

Excitatory synaptic transmission is tightly regulated by the number of active NMDARs and AMPARs at the synapse. NMDAR activation 
plays a central role, because it can induce either long-term potentiation (LTP) or long-term depression (LTD), depending on the extent of the resultant $\left[\mathrm{Ca}^{2+}\right]_{\mathrm{i}}$ rise in the dendritic spines and the downstream activation of specific intracellular cascades (Kullmann and Lamsa 2007). Activation of synaptic NMDARs and large increases in $\left[\mathrm{Ca}^{2+}\right]_{i}$ are required for LTP, whereas internalization of synaptic NMDARs, activation of perisynaptic NMDARs, and lower increases in $\left[\mathrm{Ca}^{2+}\right]_{\mathrm{i}}$ are necessary for LTD. LTP induction promotes recruitment of AMPARs and growth of dendritic spines, whereas LTD induces spine shrinkage and synaptic loss (Kullmann and Lamsa 2007).

Pathological A $\beta$ levels and assembly forms (e.g., oligomers) may indirectly cause a partial block of NMDARs and shift the activation of NMDAR-dependent signaling cascades toward pathways involved in the induction of LTD and synaptic loss (Fig. 1; Kamenetz et al. 2003; Hsieh et al. 2006; Shankar et al. 2007). This model is consistent with the fact that $A \beta$ oligomers (but not monomers) impair LTP (Walsh et al. 2002; Shankar et al. 2008; Li et al. 2011) and enhance LTD (Fig. 1; Kim et al. 2001; Hsieh et al. 2006; Li et al. 2009). Although the mechanisms underlying $A \beta$-facilitated LTD have not yet been fully elucidated, they may involve receptor internalization (Snyder et al. 2005; Hsieh et al. 2006) or desensitization (Liu et al. 2004) and subsequent collapse of dendritic spines (Snyder et al. 2005; Hsieh et al. 2006). A $\beta$-dependent effects on synaptic function may be mediated by postsynaptic activation of $\alpha 7-n A C h R$ (Snyder et al. 2005), activation of extrasynaptic NMDA receptors (Shankar et al. 2007; Li et al. 2009), and downstream effects on calcineurin/STEP/cofilin, p38 MAPK, and GSK-3 $\beta$ signaling pathways, among others (Wang et al. 2004; Shankar et al. 2007; Li et al. 2009; Tackenberg and Brandt 2009).

Another way in which soluble $A \beta$ oligomers may enhance LTD is by blocking neuronal glutamate uptake at synapses, leading to increased glutamate levels at the synaptic cleft (Fig. 2; Li et al. 2009). A resultant rise in glutamate levels would initially activate synaptic NMDARs followed by desensitization of the receptors and, ultimately, synaptic depression. Another effect of increased glutamate levels would be a spillover and activation of extra- or perisynaptic NR2B-enriched NMDARs, which play a major role in LTD induction (Liu et al. 2004) and have also been shown to help mediate the inhibition of LTP by soluble A $\beta$ oligomers ( $\mathrm{Li}$ et al. 2011). The activation of perisynaptic receptors may thus be involved in the facilitation of LTD by $A \beta$ and the inhibition of LTP (Hsieh et al. 2006; Li et al. 2009, 2011). Thus, $A \beta$-induced synaptic depression may result from an initial increase in synaptic activation of NMDARs by glutamate, followed by synaptic NMDAR desensitization, NMDAR/AMPAR internalization, and activation of extrasynaptic NMDARs and mGluRs. A $\beta$-induced LTD-like processes may underlie A $\beta$-induced LTP deficits, as blocking LTD-related signaling cascades, such as mGluR or p38 MAPK, can prevent $A \beta-$ dependent inhibition of LTP (Wang et al. 2004).

\section{WHAT ARE THE RECEPTORS BY WHICH SOLUBLE OLIGOMERS PERTURB SYNAPTIC FUNCTION?}

Although the many studies reviewed so far in this chapter have suggested some of the pathways through which elevated extracellular $A \beta$ levels particularly in the form of soluble oligomers can alter synaptic transmission, precisely how soluble $A \beta$ oligomers initiate effects on synaptic structure and function remains to be determined. Diverse lines of evidence suggest that extracellular oligomers can bind to pre- and postsynaptic elements on cultured neurons and in the AD cortex. Cellular and animal studies that have attempted to identify the molecular targets of the oligomers have yielded an array of candidates. $A \beta$ has been reported to interact functionally-and sometimes also structurally-with several distinct types of plasma membrane-anchored receptors, including $\alpha 7$ nicotinic acetylcholine receptors, NMDA and AMPA receptors, insulin receptors, RAGE (the receptor for advanced glycation end-products), the prion protein, and the Ephrin-type B2 receptor (EphB2) (Yan et al. 1999; Lacor et al. 


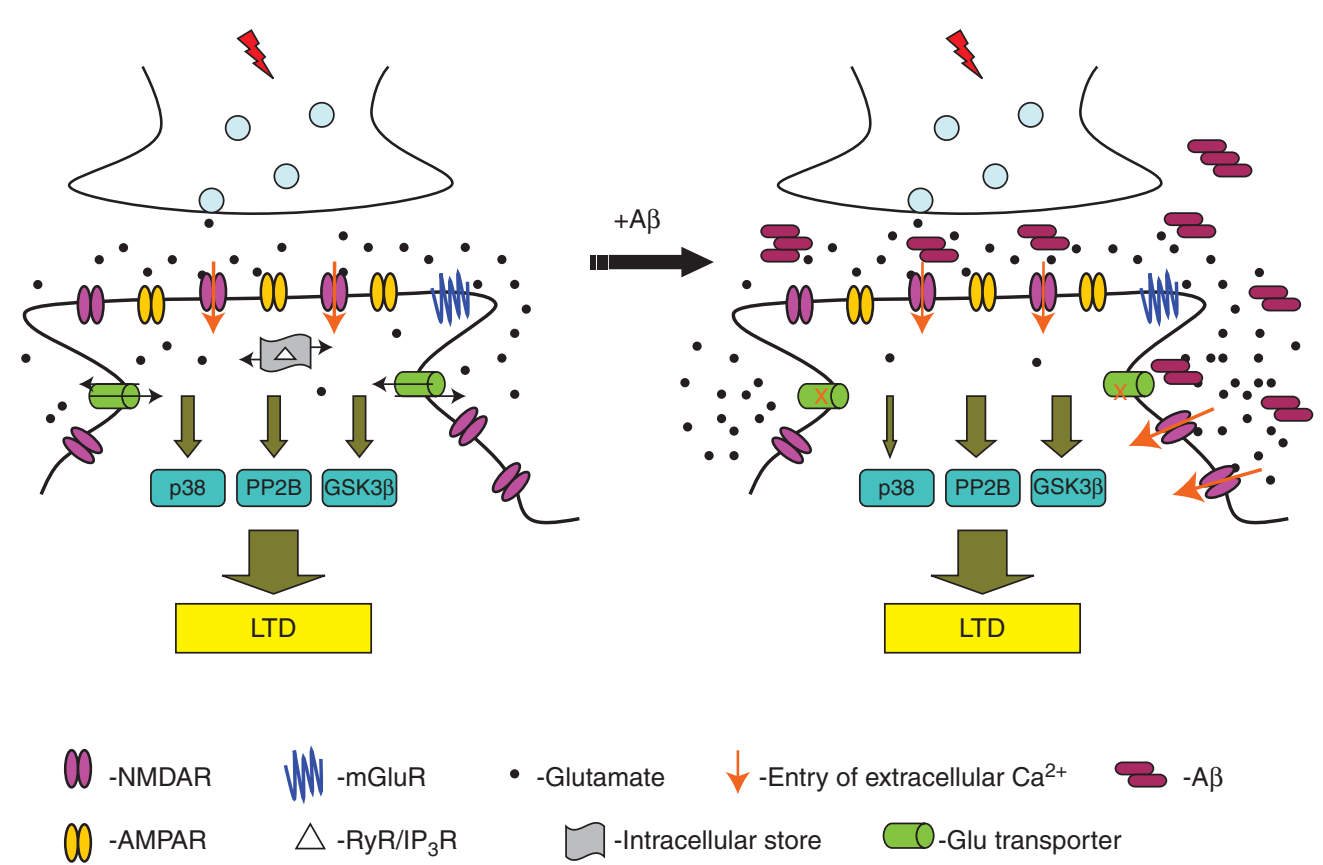

Figure 2. Schematic of the principal pathways implicated by this study in conventional LTD and in LTD facilitated by soluble $\mathrm{A} \beta$ oligomers (left panel). Conventional LTD requires NMDAR-mediated influx of extracellular calcium and liberation of intracellular calcium stores. This ultimately activates PP2B, GSK-3b, or p38 MAPK signaling pathways that induce LTD. (Right panel) Soluble A $\beta$ oligomers lead to activation of more NMDAR, leading to extracellular calcium influx and activation of PP2B and GSK-3b pathways to facilitate LTD. Our data suggest that $A \beta$ oligomers decrease glutamate uptake by neuronal transporters (red $\times$ 's), resulting in the enhanced activation of NMDARs and thus facilitation of LTD-inducing pathways.

2004; Verdier et al. 2004; Lacor et al. 2007; Simakova and Arispe 2007; Koffie et al. 2009; Lauren et al. 2009; Gimbel et al. 2010; Cisse et al. 2011a).

Several key questions should be considered in interpreting such studies. Have the investigators rigorously specified the form of $\mathrm{A} \beta$ that is binding to cultured neurons or brain sections and performed the binding studies under physiologically relevant $A \beta$ concentrations and conditions? Many studies have used synthetic $A \beta$ peptides of a single defined length (e.g., $A \beta 1-40)$ at potentially supraphysiological

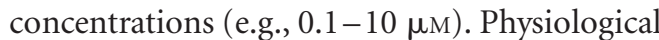
concentrations of $A \beta$ peptides in human brain, interstitial fluid and cerebrospinal fluid are in the low nanomolar range or below, although concentrations in the most pathobiologically relevant sites of the $\mathrm{AD}$ brain, for example, within and around synaptic clefts, are unknown and might be higher. Are the receptor interactions the authors report occurring with just the monomer (a physiological peptide in mammals), just certain soluble oligomers (e.g., dimers, trimers, dodecamers), and/or just protofibrils? Have the authors used biochemical methods such as size exclusion chromatography under entirely nondenaturing conditions to isolate and specify a particular assembly form, and can they assume that this form has not changed during the experiment (e.g., by recovering it intact after the exposure to neurons)?

These questions are relevant to the issue of whether secreted, soluble $A \beta$ monomers have cognate physiological receptors, analogous, for example, to tachykinin receptors for substance P. If they do (and none has yet been confirmed 
unequivocally in multiple laboratories under physiological conditions), then are there entirely different receptors that bind soluble oligomers? One would think so, as the biochemical properties of oligomers are distinct from those of the secreted monomer; for example, they are folded differently. However, preferential binding to $A \beta$ oligomers (as opposed to monomers) may not be required for a receptor to be a mediator of $A \beta$ oligomer-induced neuronal dysfunction, because interactions of the receptor with these different $\mathrm{A} \beta$ species could elicit distinct signal transduction cascades. For example, dimerization of a particular receptor might be induced by $A \beta$ oligomers but not monomers, despite comparable binding affinities. Ideally, interactions between $A \beta$ oligomers and their receptor(s) would show classical ligand-receptor binding kinetics such as those of insulin and substance $\mathrm{P}$ with their cognate receptors. However, binding of $\mathrm{A} \beta$ oligomers to some putative receptors, for example, EphB2, triggers degradation of the receptor in the proteasome (Cisse et al. 2011a), which could result in more complex kinetics.

Because soluble oligomers (e.g., dimers, trimers, dodecamers) of $\mathrm{A} \beta 42$ have exposed hydrophobic residues that allow them to bind additional monomers and they are thus highly sticky, it seems probable from a biophysical perspective that $A \beta 42$ interacts initially with other hydrophobic molecules, in particular membrane lipids, rather than relatively hydrophilic proteins like the ectodomains of the various candidate receptors mentioned above. Numerous studies using high levels of synthetic $A \beta 40$ or $A \beta 42$ indicate that such preparations can bind to membranes and perturb their structure, in some cases causing actual holes in the membrane that could conduct ions and thus induce cytotoxicity (Demuro et al. 2005; Lin et al. 2001). However, there is little evidence that such major membrane disruption occurs upon exposure of neurons to natural oligomers of secreted $A \beta$ isolated from culture media or brain tissue and applied at nanomolar concentrations. More subtle but sustained (chronic) effects of $A \beta$ oligomers on membrane lipids may well contribute to $A \beta$-induced neuronal dysfunction (Sanchez-Mejia et al. 2008), which makes the further investigation of $A \beta /$ lipid interactions an important objective.

Accordingly, we are in need of rigorous biochemical studies of fully purified natural monomers and oligomers isolated from $\mathrm{AD}$ brain tissue that are subsequently labeled, or else synthetic labeled oligomers with predetermined structures, allowing the performance of unbiased binding screens (e.g., using crosslinking) to identify which discrete surface molecules the monomers or the oligomers bind and what their binding kinetics are. Until such labor-intensive studies are performed by more than one laboratory, available data can only suggest that a particular receptor (e.g., the $\alpha 7$-nicotinic ACh receptor) plays a required role in membrane engagement and anchoring of $A \beta$ and/or its downstream biological effects, not that they necessarily represent the initial binding receptor. In addition, the pathophysiological role(s) of putative $A \beta$ oligomer receptors should be validated rigorously in relation to clinically relevant functional outcome measures in different experimental models and by independent groups, using genetic and pharmacological manipulations as well as electrophysiological, radiological, and behavioral outcome measures. For example, in independent studies, PrPc ablation either did (Lauren et al. 2009; Gimbel et al. 2010; Barry et al. 2011) or did not (Kessels and Malinow 2009; Balducci et al. 2010; Calella et al. 2010; Cisse et al. 2011b) prevent $A \beta$-induced neuronal dysfunction, leaving the functional significance of an $\mathrm{A} \beta / \mathrm{PrPc}$ interaction uncertain at this writing.

\section{EXTRACELLULAR VERSUS INTRANEURONAL $A \beta$ : EVIDENCE FOR AND AGAINST AN ATTACK BY A $\beta$ FROM WITHIN THE NEURON}

The classical histopathology of $\mathrm{AD}$ brains is characterized by large numbers of extracellular deposits of $A \beta$ in the cortical neuropil and in blood vessel walls (see Serrano-Pozo et al. 2011). This principally extracellular location is consistent with the fact that $A \beta$ arises from the intraluminal/extracellular cleavage of APP 
by $\beta$-secretase followed by the intramembranous $\gamma$-secretase cleavages that release it from the membrane into the aqueous environment of the vesicle lumen or extracellular space (Haass et al. 1992, 2011; Shoji et al. 1992). Moreover, systemic amyloids are well known to occur in the extracellular space of various tissues, not intracellularly. The application to $\mathrm{AD}$ brain sections of monoclonal antibodies to epitopes that can only be on free $A \beta$ (i.e., are not detectable in the $A \beta$ sequence when it is within the APP molecule) generally reveals enormous amounts of extracellular $A \beta$-reactive material and little or no specific staining of cell bodies. However, some careful analyses have revealed the additional presence of intraneuronal $A \beta$ immunoreactivity that appears to occur in the lumens of multivesicular bodies and some other types of intracellular vesicles (Takahashi et al. 2004, 2002; Gouras et al. 2005; Almeida et al. 2006). Such a locus is consistent with the cell biology of APP, as it has been shown in numerous studies that the proteolytic processing of APP to A $\beta$ can occur in intracellular vesicles in the secretory and endosomal trafficking pathways. Uptake of A $\beta 42$ through the endosomal/lysosomal pathway has been reported to cause lysosomal leakage (Yang et al. 1998), which could provide $A \beta$ with access to the cytosol, although the normal occurrence of cytosolic $A \beta$ has not been widely confirmed. The possible association of $A \beta$ with mitochondria (Chen and Yan 2007) also suggests that $A \beta$ can exist in these compartments. It is important to reiterate that intracellular $A \beta$ can only be established using end-specific $A \beta$ antibodies that are incapable of reacting with $A \beta$ sequences within APP and its proteolytic products present abundantly inside neurons, as has recently been emphasized (Winton et al. 2011).

The interpretation of the intravesicular $A \beta$-reactive peptides reported in neurons is not entirely clear. These peptides could represent small amounts of $A \beta$ produced by normal APP processing that is destined for secretion, or they may be in the process of being targeted for proteolytic degradation in the late endosomal/lysosomal system (see Ihara et al. 2011). It is also possible that they could represent previously secreted $A \beta$ monomers and/or oligomers that have been taken back up into cells. In this regard, it is of interest that apparent dimers of $A \beta$ have been detected by immunoprecipitation/western blotting in vesicles isolated from APP-expressing cells, including neurons (Walsh et al. 2000). The highly compact space of a vesicle lumen could afford the molecular crowding that $A \beta$ monomers may need to enhance the chances of oligomer formation, compared with the relatively dilute state of the extracellular/interstitial fluid. Another topic for consideration is whether synaptic dysfunction and neurotoxicity arise principally from intracellular $A \beta$ or from the far more abundant extracellular stores of monomers and oligomers found in $\mathrm{AD}$ brains or from both. Clearly, the extracellular application of biochemically isolated natural oligomers of $\mathrm{A} \beta$ at physiological concentrations has been shown to induce extensive neuronal changes, including altered synaptic plasticity and synapse form (Klyubin et al. 2005; Shankar et al. 2007, 2008; Li et al. 2009), abnormal tau phosphorylation progressing to neuritic dystrophy (Jin et al. 2011), and interference with memory (Cleary et al. 2005; Lesne et al. 2006; Shankar et al. 2008). One does not yet know whether a solely intraneuronal accumulation of such soluble oligomers is sufficient to induce these various AD-like phenotypes.

\section{DISRUPTION OF COGNITIVE FUNCTIONS: FROM SYNAPSES TO NEURAL NETWORKS}

The dynamic complexity of $\mathrm{A} \beta$ assembly forms is easily matched, if not outdone, by the complexity of the neural networks on which they act. Distributed networks such as the so-called "default network" comprise different brain regions, which, in turn, contain multiple interconnected circuits that are made up of distinct cell types and myriad synaptic contacts. A key unresolved question in the $\mathrm{AD}$ field is whether $\mathrm{A} \beta$ assemblies affect different neurons and synapses differentially. Answering this question is critical if one wants to predict the effects of $\mathrm{A} \beta$ on the output of neuronal circuits and the activity of networks (Palop et al. 2006; Palop 
L. Mucke and D.J. Selkoe

A

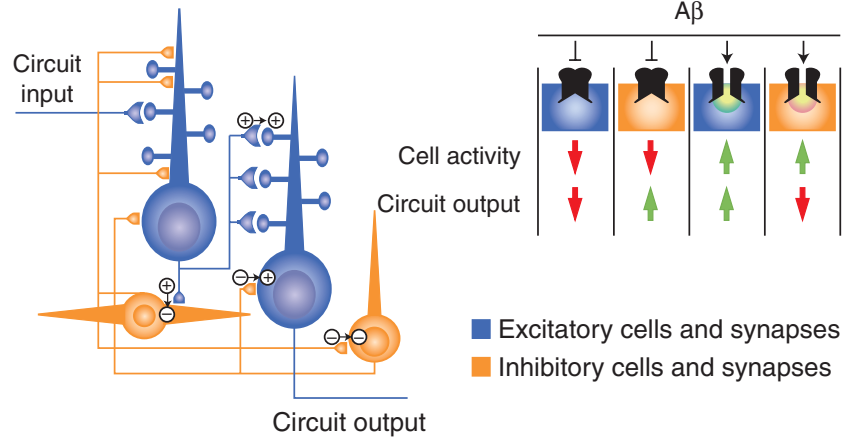

B

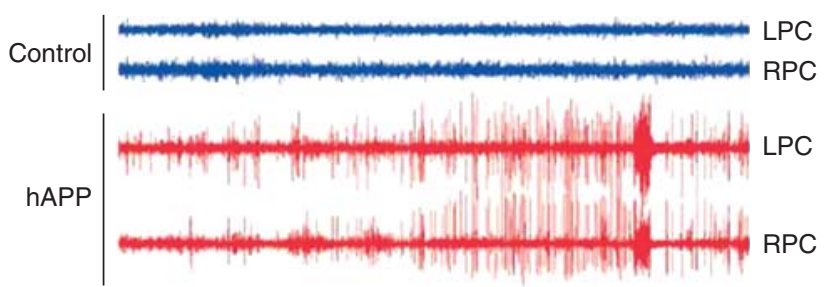

C

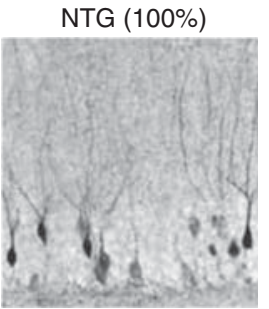

$\operatorname{hAPP}(91 \%)$

$\operatorname{hAPP}(9 \%)$
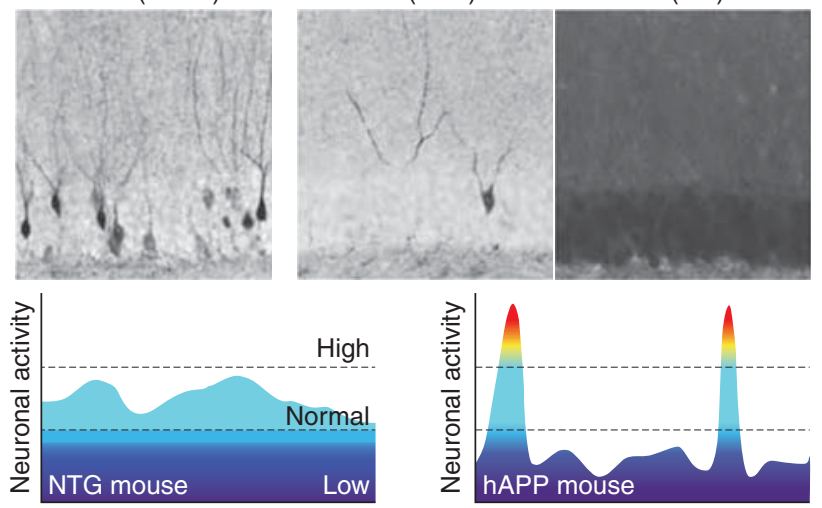

Time

Time
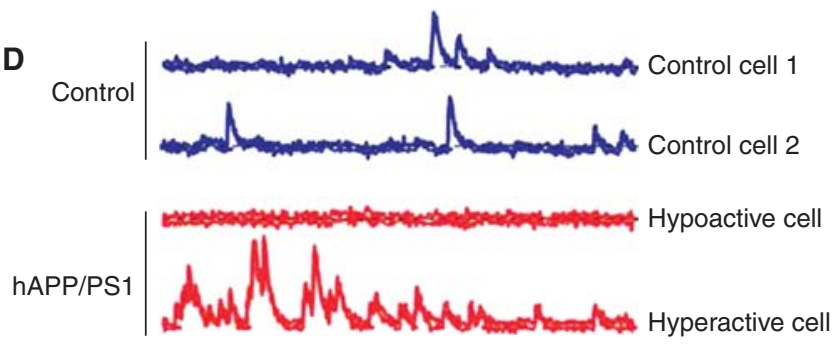

Figure 3. Pathologically elevated $A \beta$ elicits abnormal patterns of neuronal activity in circuits and in wider networks in Alzheimer disease-related mouse models. (A) Neuronal circuits are formed by synaptic interactions between excitatory and inhibitory cells. A $\beta$ might differentially affect excitatory $(+)$ and inhibitory $(-)$ synapses and cells, producing complex imbalances in circuit and network activity. ( $B$ ) At the network level, high levels of $A \beta$ increase network synchrony and elicit epileptiform activity, as illustrated here in EEG recordings from the left and right parietal cortex (LPC and RPC, respectively) of nontransgenic (NTG) controls (blue) and hAPP transgenic mice from line J20 (red). (C) hAPP mice show fluctuations in the neuronal expression of synaptic activity-dependent genes, suggesting network instability. (See facing page for legend.) 
and Mucke 2010). For example, if $A \beta$ impaired the synaptic function of inhibitory interneurons more than that of excitatory principal cells, it would be likely to cause disinhibition and overexcitation, rather than suppression, at the network level (Fig. 3). A similar effect would result if $A \beta$ suppressed excitatory $\rightarrow$ inhibitory synapses more than excitatory $\rightarrow$ excitatory synapses.

Experimental evidence suggests that some GABAergic neurons may indeed be especially vulnerable to $A \beta$, which helps explain apparent discrepancies between results obtained in analyses of specific synapses versus circuits and networks. Early electrophysiological studies focused on two specific glutamatergic synapses in the hippocampus, the CA3 $\rightarrow$ Schaffer collateral $\rightarrow$ CA1 pyramidal cell synapse and the entorhinal cortex $\rightarrow$ perforant path $\rightarrow$ dentate gyrus granule cell synapse. At these synapses, $\mathrm{A} \beta$ has been reported in numerous studies to suppress transmission strength and/or longand short-term plasticity (see Palop and Mucke 2010 for review). Based on just these two circuits, it might be expected that $\mathrm{A} \beta$ primarily suppresses network excitability, but this is not what actually happens in vivo.

Among the first clues suggesting that $A \beta$ can elicit aberrant excitatory activity at the network level was the identification of anatomical and biochemical alterations in the dentate gyrus of hAPP mice that are typically seen in rodent models of epilepsy or other states of neuronal overexcitation. These alterations include reductions in calbindin and increases in neuropeptide Y (NPY; Palop et al. 2003; Palop et al. 2007). Video electroencephalogram (EEG) telemetry recordings in freely behaving hAPP mice have detected widespread cortical and hippocampal epileptiform activity (Palop et al. 2007; Minkeviciene et al. 2009; Vogt et al. 2009; Roberson et al. 2011). Some of these EEG studies also documented intermittent, nonconvulsive seizures that were difficult or impossible to detect by visual observation. Although some lines of hAPP mice have frank convulsive seizures, such events appear to be rare in most hAPP mice. Convulsive seizures are also rare in sporadic $\mathrm{AD}$, although this condition is clearly associated with an increased incidence of epilepsy (reviewed in Palop and Mucke 2009). Interestingly, clinically apparent seizures are much more common in cases with early-onset $\mathrm{AD}$, particularly autosomal dominant pedigrees and $\mathrm{AD}$ associated with Down syndrome, suggesting a potentially causal role of high $A \beta$ levels and aggressive cytopathology. The incidence of nonconvulsive (subclinical) seizure activity in familial and sporadic AD is unknown. Studies have recently been launched in multiple centers to address this intriguing issue.

Additional studies are also needed to elucidate the precise mechanisms by which $A \beta$ elicits aberrant excitatory network activity. The possibilities include direct proexcitatory effects on principal glutamatergic neurons and impairments of inhibitory interneurons that therefore indirectly disinhibit the network (Palop et al. 2007; Busche et al. 2008; Palop and Mucke 2010). Acutely, exposure to synthetic or natural $A \beta$ assemblies can increase neuronal activity in cell culture and cortical slices (Sanchez-Mejia et al. 2008; Supnet and Bezprozvanny 2010). The underlying mechanisms may involve increases in $\left[\mathrm{Ca}^{2+}\right]_{\mathrm{i}}$, activation of group IVA phospholipase $\mathrm{A}_{2}$ (GIVA-PLA $\mathrm{A}_{2}$ ), increased release of arachidonic acid, and/or transient increases in surface levels of glutamate

Figure 3. (Continued) Top: Compared with NTG controls (left), hAPP-J20 mice show abnormally low (middle) or high (right) Arc expression in granule cells of the dentate gyrus (adapted, with permission, from Palop et al. 2005, 2007). Percentages indicate the proportion of mice showing the different patterns of Arc expression. Such marked increases in Arc expression are typically caused by seizure activity. Bottom: Interpretive diagram. Marked fluctuations in neuronal activity may directly impair cognition by reducing the time the network spends in activity patterns that promote normal cognitive functions. $(D)$ In cortical circuits of mice monitored in vivo by calcium imaging, most neurons in NTG controls (blue traces) have an intermediate level of activity, whereas many neurons in hAPP/PS1 transgenic mice with high A $\beta$ levels (red traces) are either hypoactive (top) or hyperactive (bottom). (Adapted, with permission, from Palop and Mucke 2010.) 
receptors. Chronically, $A \beta$ appears to interfere with neuronal glutamate transporters, resulting in increased levels of glutamate in and around the synaptic cleft, desensitization of glutamate receptors and engagement of LTD-related signaling pathways (Hsieh et al. 2006; Li et al. 2009; Wei et al. 2010). Pathogenic glial loops resulting in the production of excitotoxins may contribute as well. $A \beta$ also increases metenkaphalin levels in the hippocampus and entorhinal cortex, which could suppress the activity of inhibitory interneurons via stimulation of $\mu$-opioid receptors. Indeed, pharmacological blockade of these receptors improved the performance of hAPP mice in the Morris water maze (Meilandt et al. 2008).

Overexcitation or hypersynchrony of neural networks triggers a multitude of compensatory responses, including extensive remodeling of neuronal circuits. This leads to a complex combination of decreased (probably primary) and increased (probably secondary) inhibitory pathways. For example, whereas hAPP mice show evidence for impaired function of GABAergic interneurons (Busche et al. 2008; Roberson et al. 2011), the outer molecular layers of their dentate gyri have extensive sprouting of GABAergic terminals, and their granule cells receive an increased number of inhibitory inputs (Palop et al. 2007). In addition, their mossy fiber collaterals contact basket cells, which would be expected to result in feed-forward inhibition of the granule cells from which the mossy fibers emanate. These alterations are consistent with the idea that the dentate gyrus, which epileptologists regard as the "gate" to the hippocampus, can activate mechanisms to block $A \beta$-induced aberrant excitatory activity. Much of this excess activity probably originates in cortical areas (Harris et al. 2010).

It is likely that, in $\mathrm{AD}$ and mouse models thereof, compensatory inhibitory mechanisms manage to delay and diminish excitotoxic processes that ultimately cause loss of synapses and neurons. However, these mechanisms may simultaneously constrain the agility of excitatory processes required for normal learning and memory. In addition, they probably contribute to a "yin and yang" between too much and too little neuronal activity, diminishing the amount of time networks spend in a physiological range of activity that is conducive to normal cognitive functions (Fig. 3C). Direct evidence for such fluctuations comes from studies monitoring neuronal expression of the activity-related gene product Arc in dentate granule cells or calcium fluxes in neocortical neurons of live hAPP mice (Palop et al. 2007; Busche et al. 2008).

\section{THERAPEUTIC IMPLICATIONS OF THE CONCEPT THAT A $\beta$-MEDIATED NEUROTOXICITY OCCURS PRINCIPALLY AT THE LEVEL OF SYNAPTIC NETWORKS}

What are the therapeutic implications of the complex synaptic and network alterations reviewed in this chapter? First, AD is a slowly progressive and highly dynamic process, with different mechanisms probably predominating at different stages of the disease. Supporting this notion, recent studies show that detrimental effects of $A \beta$ on adult-born granule cells can be prevented by inhibiting $\mathrm{GABA}_{\mathrm{A}}$ receptors during early stages of their development or by enhancing glutamatergic signaling during later stages of maturation (Sun et al. 2009). Second, if aberrant increases in network excitability or synchronization are indeed early/ proximal events in the $A \beta$-triggered pathogenic cascade, identifying ways to block this process becomes a critical therapeutic objective. The effect of antiepileptic drugs has not yet been rigorously evaluated in patients with early $\mathrm{AD}$, and the optimal drug to block $\mathrm{A} \beta$-induced aberrant excitatory neuronal activity in experimental models has yet to be identified. It will probably have to target the specific mechanisms by which $A \beta$ elicits aberrant excitatory neuronal activity, which also remain to be pinpointed.

A pragmatic way forward to deal with the complex cellular and network alterations that occur during $\mathrm{AD}$ is to lower the levels of $\mathrm{A} \beta$ itself by inhibiting its production or enhancing its removal (see Schenk et al. 2011). Several such strategies are currently being assessed in human trials. At this writing, it remains unsettled whether such strategies will be efficacious and 
safe (Golde et al. 2011; Selkoe 2011). For some of them, it is still uncertain whether they actually lower the levels of those $A \beta$ assemblies that have the greatest impact on neuronal form and function. It therefore makes sense to complement these approaches with strategies that might make the brain more resistant to $A \beta$ by targeting copathogenic factors or downstream mechanisms.

Examples of the latter strategies include reductions in the levels of the microtubuleassociated protein tau (Roberson et al. 2007, 2011; Ittner et al. 2010; Jin et al. 2011; Morris et al. 2011) or of GIVA-PLA, (Sanchez-Mejia et al. 2008) or replacement of apoE4 function with apoE3-like function (Raber et al. 2000; Buttini et al. 2002; Mahley et al. 2006). Although the precise mechanisms by which these and similar interventions prevent $A \beta$-induced cognitive impairments without reducing $A \beta$ levels remain to be determined, they may share a general effect of making the brain more resistant to aberrant excitatory synaptic activity. For example, even partial (50\%) reduction of endogenous wild-type murine tau prevented synaptic and behavioral deficits in hAPP-J20 mice as well as evidence of neuronal overexcitation (Roberson et al. 2007; Morris et al. 2011; Roberson et al. 2011). Surprisingly, it did so without affecting $A \beta$ levels, plaque formation or neuritic dystrophy. Similarly, knockdown of tau in cultured neurons made them markedly resistant to the cytoskeletal disruption and neuritic dystrophy induced by natural oligomers of $\mathrm{A} \beta$ isolated from $\mathrm{AD}$ cortex (Jin et al. 2011). Hippocampal slices from tau knockout mice were resistant to the LTP inhibition caused by synthetic $A \beta$ peptide (Shipton et al. 2011). Tau reduction has also been shown to make mice with or without $\mathrm{hAPP} / \mathrm{A} \beta$ overexpression more resistant to chemically induced seizures (Roberson et al. 2007; Ittner et al. 2010), suggesting a previously unrecognized role of tau in the regulation of neuronal activity. These various findings raise the intriguing possibility that nonaggregated wild-type tau fulfills a normal neuronal function that is required for $A \beta$ and other excitotoxins to elicit aberrant excitatory activity.
Although the relative amounts of specific isoforms of tau and its exact amino acid sequence differ in mice and humans, the longest tau isoforms expressed in human and mouse brain are $88 \%$ identical and 92\% similar. Proteins that are this highly conserved in amino acid sequence are likely to have conserved functions. Therefore, investigating the functions of mouse tau in transgenic models should provide clues regarding the roles of human tau in health and disease. This is particularly so because the enabling role of endogenous tau in $A \beta$-induced neuronal dysfunction probably does not depend on direct interactions between $A \beta$ and tau, which are localized to separate compartments of the neuron. Instead, it may depend on permissive activities of tau, such as facilitation of neuronal excitability (Ittner et al. 2010), that are likely conserved in mice and humans. Such hypothetical tau functions could play a critical role in the pathogenesis of dementia and are not inconsistent with evidence that pathogenic tau aggregates cause neurodegeneration in $\mathrm{AD}$ and other tauopathies (Hoover et al. 2010; Zempel et al. 2010).

Intuitively, it makes sense that loss of neurons is a principal basis for cognitive decline in $\mathrm{AD}$ and other neurodegenerative dementias. However, several observations suggest that one should not view it as the sine qua non of functional decline, particularly early on in the syndrome. For example, the brain can compensate quite well for major losses of neurons, especially when these losses occur over prolonged periods of time. A striking example is a patient with longstanding communicating hydrocephalus who has only a rim of cortical ribbon left but functions quite well despite remarkably abnormal brain scans (Lewin 1980). Importantly, in APP transgenic mice, $A \beta$ accumulation elicits severe synaptic impairments and unequivocal deficits in learning and memory without causing major neuronal loss, although neurites do degenerate. In tau transgenic mice, cognitive deficits are associated with neuronal loss, but these deficits can be reversed despite the persistence of the neuronal loss (SantaCruz et al. 2005).

Taken together, available data reviewed here and elsewhere raise the possibility that a 
significant proportion of the profound cognitive and behavioral deficits in $\mathrm{AD}$ patients are due to the dysfunction of synapses and neural networks (Selkoe 2002; Palop and Mucke 2010). This concept has far-reaching therapeutic implications. While the replacement and proper integration of whole neurons remains a very major challenge, the regeneration of neurites, the re-establishment of synaptic contacts and an improvement of network function appear within somewhat closer experimental reach. Fostering such restorative processes while also trying to diminish or block factors that fuel the progression of $\mathrm{AD}$, such as $\mathrm{A} \beta$ and tau accumulation, should slow and ultimately even prevent cognitive dysfunction in this dauntingly complex syndrome.

\section{REFERENCES}

${ }^{*}$ Reference is also in this collection.

Abramov E, Dolev I, Fogel H, Ciccotosto GD, Ruff E, Slutsky I. 2009. Amyloid- $\beta$ as a positive endogenous regulator of release probability at hippocampal synapses. Nat Neurosci 12: 1567-1576.

Almeida CG, Takahashi RH, Gouras GK. 2006. $\beta$-Amyloid accumulation impairs multivesicular body sorting by inhibiting the ubiquitin-proteasome system. J Neurosci 26: $4277-4288$.

Balducci C, Beeg M, Stravalaci M, Bastone A, Sclip A, Biasini E, Tapella L, Colombo L, Manzoni C, Borsello T, et al. 2010. Synthetic amyloid- $\{\beta\}$ oligomers impair long-term memory independently of cellular prion protein. Proc Natl Acad Sci 107: 2295-2300.

Barry AE, Klyubin I, McDonald JM, Mably AJ, Farrell MA, Scott M, Walsh DM, Rowan MJ. 2011. Alzheimer's disease brain-derived amyloid-mediated inhibition of LTP in vivo is prevented by immunotargeting cellular prion protein. J Neurosci 31: 7259-7263.

Bitan G, Lomakin A, Teplow DB. 2001. Amyloid $\beta$-protein oligomerization: Prenucleation interactions revealed by photo-induced cross-linking of unmodified proteins. J Biol Chem 276: 35176-35184.

Busche MA, Eichhoff G, Adelsberger H, Abramowski D, Wiederhold KH, Haass C, Staufenbiel M, Konnerth A, Garaschuk O. 2008. Clusters of hyperactive neurons near amyloid plaques in a mouse model of Alzheimer's disease. Science 321: 1686-1689.

Buttini M, Yu G-Q, Shockley K, Huang Y, Jones B, Masliah E, Mallory M, Yeo T, Longo FM, Mucke L. 2002. Modulation of Alzheimer-like synaptic and cholinergic deficits in transgenic mice by human apolipoprotein E depends on isoform, aging, and overexpression of amyloid $\beta$ peptides but not on plaque formation. J Neurosci 22: 10539-10548.
Calella AM, Farinelli M, Nuvolone M, Mirante O, Moos R, Falsig J, Mansuy IM, Aguzzi A. 2010. Prion protein and A $\beta$-related synaptic toxicity impairment. EMBO Mol Med 2: 306-314.

Chen JX, Yan SD. 2007. Amyloid- $\beta$-induced mitochondrial dysfunction. J Alzheimer's Dis 12: 177-184.

Cirrito JR, Yamada KA, Finn MB, Sloviter RS, Bales KR, May PC, Schoepp DD, Paul SM, Mennerick S, Holtzman DM. 2005. Synaptic activity regulates interstitial fluid amyloid- $\beta$ levels in vivo. Neuron 48: 913-922.

Cisse M, Halabisky B, Harris JA, Devidze N, Dubal D, Lotz G, Kim DH, Hamto T, Ho K, Yu G-Q, et al. 2011 a. Reversing EphB2 depletion rescues cognitive functions in Alzheimer model. Nature 469: 47-52.

Cisse M, Sanchez PE, Kim DH, Yu G-Q, Mucke L. 2011 b. Ablation of cellular prion protein does not ameliorate abnormal neural network activity and cognitive dysfunction in the J20 line of human amyloid precursor protein transgenic mice. J Neurosci 31: 10427-10431.

Cleary JP, Walsh DM, Hofmeister JJ, Shankar GM, Kuskowski MA, Selkoe DJ, Ashe KH. 2005. Natural oligomers of the amyloid- $\beta$ protein specifically disrupt cognitive function. Nat Neurosci 8: 79-84.

DeKosky ST, Scheff SW. 1990. Synapse loss in frontal cortex biopsies in Alzheimer's disease: Correlation with cognitive severity. Ann Neurol 27: 457-464.

Demuro A, Mina E, Kayed R, Milton SC, Parker I, Glabe CG. 2005. Calcium dysregulation and membrane disruption as a ubiquitous neurotoxic mechanism of soluble amyloid oligomers. J Biol Chem 280: 17294-17300.

Dineley KT, Bell KA, Bui D, Sweatt JD. 2002. $\beta$-Amyloid peptide activates $\alpha 7$ nicotinic acetylcholine receptors expressed in Xenopus oocytes. J Biol Chem 277: 25056-25061.

Gimbel DA, Nygaard HB, Coffey EE, Gunther EC, Lauren J, Gimbel ZA, Strittmatter SM. 2010. Memory impairment in transgenic Alzheimer mice requires cellular prion protein. J Neurosci 30: 6367-6374.

Golde TE, Schneider LS, Koo EH. 2011. Anti-aß therapeutics in Alzheimer's disease: The need for a paradigm shift. Neuron 69: 203-213.

Gong Y, Chang L, Viola KL, Lacor PN, Lambert MP, Finch CE, Krafft GA, Klein WL. 2003. Alzheimer's diseaseaffected brain: Presence of oligomeric A $\beta$ ligands (ADDLs) suggests a molecular basis for reversible memory loss. Proc Natl Acad Sci 100: 10417-10422.

Gouras GK, Almeida CG, Takahashi RH. 2005. Intraneuronal $A \beta$ accumulation and origin of plaques in $\mathrm{Alz}-$ heimer's disease. Neurobiol Aging 26: 1235-1244.

Haass C, Schlossmacher M, Hung AY, Vigo-Pelfrey C, Mellon A, Ostaszewski B, Lieberburg I, Koo EH, Schenk D, Teplow D, et al. 1992. Amyloid $\beta$-peptide is produced by cultured cells during normal metabolism. Nature 359: $322-325$.

* Haass C, Kaether C, Sisodia S, Thinakaran G. 2011. Trafficking and proteolytic processing of APP. Cold Spring Harb Perspect Med doi: 10.1101/cshperspect.a006270.

Hardy JA, Higgins GA. 1992. Alzheimer's disease: The amyloid cascade hypothesis. Science 256: 184-185. 
Harper JD, Wong SS, Lieber CM, Lansbury PT Jr. 1997. Observation of metastable $\mathrm{Ab}$ amyloid protofibrils by atomic force microscopy. Chem Biol 4: 119-125.

Harris JA, Devidze N, Verret L, Ho K, Hamto T, Lo I, Yu G-Q, Palop JJ, Masliah E, Mucke L. 2010. Transsynaptic progression of amyloid- $\beta$-induced neuronal dysfunction within the entorhinal-hippocampal network. Neuron 68: $428-441$.

Hartley D, Walsh DM, Ye CP, Diehl T, Vasquez S, Vassilev PM, Teplow DB, Selkoe DJ. 1999. Protofibrillar intermediates of amyloid $\beta$-protein induce acute electrophysiological changes and progressive neurotoxicity in cortical neurons. J Neurosci 19: 8876-8884.

Holcomb LA, Gordon MN, Jantzen P, Hsiao K, Duff K, Morgan D. 1999. Behavioral changes in transgenic mice expressing both amyloid precursor protein and presenilin-1 mutations: Lack of association with amyloid deposits. Behav Genet 29: 177-185.

Hoover BR, Reed MN, Su J, Penrod RD, Kotilinek LA, Grant MK, Pitstick R, Carlson GA, Lanier LM, Yuan LL, et al. 2010. Tau mislocalization to dendritic spines mediates synaptic dysfunction independently of neurodegeneration. Neuron 68: 1067-1081.

Hsia AY, Masliah E, McConlogue L, Yu GQ, Tatsuno G, Hu K, Kholodenko D, Malenka RC, Nicoll RA, Mucke L. 1999. Plaque-independent disruption of neural circuits in Alzheimer's disease mouse models. Proc Natl Acad Sci 96: 3228-3233.

Hsieh H, Boehm J, Sato C, Iwatsubo T, Tomita T, Sisodia S, Malinow R. 2006. AMPAR removal underlies $A \beta$ induced synaptic depression and dendritic spine loss. Neuron 52: 831-843.

Hyman BT, West HL, Rebeck GW, Buldyrev SV, Mantegna RN, Ukleja M, Havlin S, Stanley HE. 1995. Quantitative analysis of senile plaques in Alzheimer's disease: Observation of log-normal size distribution and molecular epidemiology of differences associated with apolipoprotein E genotype and trisomy 21 (Down syndrome). Proc Natl Acad Sci 92: 3586-3590.

* Ihara Y, Morishima-Kawashima M, Nixon R. 2011. The ubiquitin-proteasome system and the autophagiclysosomal system in Alzheimer disease. Cold Spring Harb Perspect Med doi: 10.1101/cshperspect.a006361.

Ittner LM, Ke YD, Delerue F, Bi M, Gladbach A, van Eersel J, Wolfing H, Chieng BC, Christie MJ, Napier IA, et al. 2010. Dendritic function of tau mediates amyloid- $\beta$ toxicity in Alzheimer's disease mouse models. Cell 142: 387-397.

Jin M, Shepardson N, Yang T, Walsh D, Selkoe D. 2011. Soluble amyloid $\beta$-protein dimers isolated from Alzheimer cortex directly induce Tau hyperphosphorylation and neuritic degeneration. Proc Natl Acad Sci 108: 5819-5824.

Kamenetz F, Tomita T, Hsieh H, Seabrook G, Borchelt D, Iwatsubo T, Sisodia S, Malinow R. 2003. APP processing and synaptic function. Neuron 37: 925-937.

Kang JE, Lim MM, Bateman RJ, Lee JJ, Smyth LP, Cirrito JR, Fujiki N, Nishino S, Holtzman DM. 2009. Amyloid- $\beta$ dynamics are regulated by orexin and the sleep-wake cycle. Science 326: 1005-1007.

Kawarabayashi T, Younkin LH, Saido TC, Shoji M, Ashe KH, Younkin SG. 2001. Age-dependent changes in brain, CSF and plasma amyloid $(\beta)$ protein in the Tg2576 transgenic mouse model of Alzheimer's disease. J Neurosci 21 $372-381$.

Kayed R, Head E, Thompson JL, McIntire TM, Milton SC, Cotman CW, Glabe CG. 2003. Common structure of soluble amyloid oligomers implies common mechanism of pathogenesis. Science 300: 486-489.

Kessels HW, Malinow R. 2009. Synaptic AMPA receptor plasticity and behavior. Neuron 61: 340-350.

Kim JH, Anwyl R, Suh YH, Djamgoz MB, Rowan MJ. 2001. Use-dependent effects of amyloidogenic fragments of $(\beta)$-amyloid precursor protein on synaptic plasticity in rat hippocampus in vivo. J Neurosci 21 1327-1333.

Klyubin I, Walsh DM, Lemere CA, Cullen WK, Shankar GM, Betts V, Spooner ET, Jiang L, Anwyl R, Selkoe DJ, et al. 2005. Amyloid $\beta$ protein immunotherapy neutralizes $A \beta$ oligomers that disrupt synaptic plasticity in vivo. Nat Med 11: 556-561.

Koffie RM, Meyer-Luehmann M, Hashimoto T, Adams KW, Mielke ML, Garcia-Alloza M, Micheva KD, Smith SJ, Kim ML, Lee VM, et al. 2009. Oligomeric amyloid $\beta$ associates with postsynaptic densities and correlates with excitatory synapse loss near senile plaques. Proc Natl Acad Sci 106: 4012-4017.

Kullmann DM, Lamsa KP. 2007. Long-term synaptic plasticity in hippocampal interneurons. Nat Rev Neurosci 8: 687-699.

Lacor PN, Buniel MC, Chang L, Fernandez SJ, Gong Y, Viola KL, Lambert MP, Velasco PT, Bigio EH, Finch CE, et al. 2004. Synaptic targeting by Alzheimer's-related amyloid $\beta$ oligomers. J Neurosci 24: 10191-10200.

Lacor PN, Buniel MC, Furlow PW, Clemente AS, Velasco PT, Wood M, Viola KL, Klein WL. 2007. A $\beta$ oligomerinduced aberrations in synapse composition, shape, and density provide a molecular basis for loss of connectivity in Alzheimer's disease. J Neurosci 27: 796-807.

Laird FM, Cai H, Savonenko AV, Farah MH, He K, Melnikova T, Wen H, Chiang HC, Xu G, Koliatsos VE, et al. 2005. BACE1, a major determinant of selective vulnerability of the brain to amyloid- $\beta$ amyloidogenesis, is essential for cognitive, emotional, and synaptic functions. J Neurosci 25: 11693-11709.

Lambert MP, Barlow AK, Chromy BA, Edwards C, Freed R, iosatos M, Morgan TE, Rozovsky I, Trommer B, Viola KL, et al. 1998. Diffusible, nonfribrillar ligands derived from $\mathrm{A} \beta_{1-42}$ are potent central nervous system neurotoxins. Proc Natl Acad Sci 95: 6448-6453.

Lauren J, Gimbel DA, Nygaard HB, Gilbert JW, Strittmatter SM. 2009. Cellular prion protein mediates impairment of synaptic plasticity by amyloid- $\beta$ oligomers. Nature 457 : $1128-1132$.

Lesne S, Koh MT, Kotilinek L, Kayed R, Glabe CG, Yang A, Gallagher M, Ashe KH. 2006. A specific amyloid- $\beta$ protein assembly in the brain impairs memory. Nature 440: 352-357.

Lewin R. 1980. Is your brain really necessary? Science 210: $1232-1234$

Li S, Hong S, Shepardson NE, Walsh DM, Shankar GM, Selkoe D. 2009. Soluble oligomers of amyloid $\beta$ protein facilitate hippocampal long-term depression by disrupting neuronal glutamate uptake. Neuron 62: 788-801. 
Li S, Jin M, Koeglsperger T, Shepardson NE, Shankar GM Selkoe DJ. 2011. Soluble A $\beta$ oligomers inhibit long-term potentiation through a mechanism involving excessive activation of extrasynaptic NR2B-containing NMDA receptors. J Neurosci 31: 6627-6638.

Lin H, Bhatia R, Lal R. 2001. Amyloid $\beta$ protein forms ion channels: Implications for Alzheimer's disease pathophysiology. FASEB J 15: 2433-2444.

Liu L, Wong TP, Pozza MF, Lingenhoehl K, Wang Y, Sheng M, Auberson YP, Wang YT. 2004. Role of NMDA receptor subtypes in governing the direction of hippocampal synaptic plasticity. Science 304: 1021-1024.

Mahley RW, Weisgraber KH, Huang Y. 2006. Apolipoprotein E4: A causative factor and therapeutic target in neuropathology, including Alzheimer's disease. Proc Natl Acad Sci 103: 5644-5651.

Martins IC, Kuperstein I, Wilkinson H, Maes E, Vanbrabant M, Jonckheere W, Van Gelder P, Hartmann D, D'Hooge R, De Strooper B, et al. 2008. Lipids revert inert A $\beta$ amyloid fibrils to neurotoxic protofibrils that affect learning in mice. Embo J 27: 224-233.

McLaurin J, Kierstead ME, Brown ME, Hawkes CA, Lambermon MH, Phinney AL, Darabie AA, Cousins JE, French JE, Lan MF, et al. 2006. Cyclohexanehexol inhibitors of $A \beta$ aggregation prevent and reverse Alzheimer phenotype in a mouse model. Nat Med 12: 801-808.

McLean CA, Cherny RA, Fraser FW, Fuller SJ, Smith MJ, Beyreuther K, Bush AI, Masters CL. 1999. Soluble pool of A $\beta$ amyloid as a determinant of severity of neurodegeneration in Alzheimer's disease. Ann Neurol 46: 860-866.

Meilandt WJ, Yu G-Q, Chin J, Roberson ED, Palop JJ, Wu T, Scearce-Levie K, Mucke L. 2008. Enkephalin elevations contribute to neuronal and behavioral impairments in a transgenic mouse model of Alzheimer's disease. J Neurosci 28: 5007-5017.

Minkeviciene R, Rheims S, Dobszay MB, Zilberter M, Hartikainen J, Fulop L, Penke B, Zilberter Y, Harkany T, Pitkanen A, et al. 2009. Amyloid $\beta$-induced neuronal hyperexcitability triggers progressive epilepsy. J Neurosci 29: 3453-3462.

Morris M, Maeda S, Vossel K, Mucke L. 2011. The many faces of tau. Neuron 70: 410-426.

Mucke L, Masliah E, Yu GQ, Mallory M, Rockenstein EM, Tatsuno G, Hu K, Kholodenko D, Johnson-Wood K, McConlogue L. 2000. High-level neuronal expression of $\mathrm{a} \beta$ 1-42 in wild-type human amyloid protein precursor transgenic mice: Synaptotoxicity without plaque formation. J Neurosci 20: 4050-4058.

Palop JJ, Mucke L. 2009. Epilepsy and cognitive impairments in Alzheimer disease. Arch Neurol 66: 435-440.

Palop JJ, Mucke L. 2010. Amyloid- $\beta$-induced neuronal dysfunction in Alzheimer's disease: From synapses toward neural networks. Nat Neurosci 13: 812-818.

Palop JJ, Jones B, Kekonius L, Chin J, Yu G-Q, Raber J, Masliah E, Mucke L. 2003. Neuronal depletion of calciumdependent proteins in the dentate gyrus is tightly linked to Alzheimer's disease-related cognitive deficits. Proc Natl Acad Sci 100: 9572-9577.

Palop JJ, Chin J, Bien-Ly N, Massaro C, Yeung BZ, Yu GQ, Mucke L. 2005. Vulnerability of dentate granule cells to disruption of arc expression in human amyloid precursor protein transgenic mice. J Neurosci 25: 9686-9693.
Palop JJ, Chin J, Mucke L. 2006. A network dysfunction perspective on neurodegenerative diseases. Nature 443: $768-773$.

Palop JJ, Chin J, Roberson ED, Wang J, Thwin MT, Bien-Ly N, Yoo J, Ho KO, Yu G-Q, Kreitzer A, et al. 2007. Aberrant excitatory neuronal activity and compensatory remodeling of inhibitory hippocampal circuits in mouse models of Alzheimer's disease. Neuron 55: 697-711.

Podlisny MB, Ostaszewski BL, Squazzo SL, Koo EH, Rydel RE, Teplow DB, Selkoe DJ. 1995a. Aggregation of secreted amyloid $\beta$-protein into SDS-stable oligomers in cell culture. J Biol Chem 270: 9564-9570.

Puzzo D, Privitera L, Leznik E, Fa M, Staniszewski A, Palmeri A, Arancio O. 2008. Picomolar amyloid- $\beta$ positively modulates synaptic plasticity and memory in hippocampus. J Neurosci 28: 14537-14545.

Raber J, Wong D, Yu G-Q, Buttini M, Mahley RW, Pitas RE, Mucke L. 2000. Alzheimer's disease: Apolipoprotein E and cognitive performance. Nature 404: 352-354.

Roberson ED, Halabisky B, Yoo JW, Yao J, Chin J, Yan F, Wu T, Hamto P, Devidze N, Yu G-Q, et al. 2011. Amyloid- $\beta$ / Fyn-induced synaptic, network, and cognitive impairments depend on Tau levels in multiple mouse models of Alzheimer's disease. J Neurosci 31: 700-711.

Roberson ED, Scearce-Levie K, Palop JJ, Yan F, Cheng IH, Wu T, Gerstein H, Yu G-Q, Mucke L. 2007. Reducing endogenous tau ameliorates Amyloid beta-induced deficits in an Alzheimer's disease mouse model. Science 316: 750-754.

Roher AE, Chaney MO, Kuo Y-M, Webster SD, Stine WB, Haverkamp LJ, Woods AS, Cotter RJ, Tuohy JM, Krafft GA, et al. 1996. Morphology and toxicity of Aß-(1-42) dimer derived from neuritic and vascular amyloid deposits of Alzheimer's disease. J Biol Chem 271: 20631-20635.

Sanchez-Mejia RO, Newman JW, Toh S, G-Q Y, Zhou Y, Halabisky B, Cisse M, Scearce-Levie K, Cheng IH, Gan L, et al. 2008. Phospholipase A2 reduction ameliorates cognitve deficits in mouse model of Alzheimer's disease. Nat Neurosci 11: 1311-1318.

SantaCruz K, Lewis J, Spires T, Paulson J, Kotilinek L, Ingelsson M, Guimaraes A, DeTure M, Ramsden M, McGowan E, et al. 2005. Tau suppression in a neurodegenerative mouse model improves memory function. Science 309: $476-481$.

Saura CA, Choi SY, Beglopoulos V, Malkani S, Zhang D, Shankaranarayana Rao BS, Chattarji S, Kelleher RJ, Kandel ER, Duff K, et al. 2004. Loss of presenilin function causes impairments of memory and synaptic plasticity followed by age-dependent neurodegeneration. Neuron 42: $23-36$

* Schenk D, Basi GS, Pangalos MN. 2011. Treatment strategies targeting amyloid $\beta$-protein. Cold Spring Harb Perspect Med doi: 10.1101/cshperspect.a006387.

Seabrook GR, Smith DW, Bowery BJ, Easter A, Reynolds T, Fitzjohn SM, Morton RA, Zheng H, Dawson GR, Sirinathsinghji DJS, et al. 1999. Mechanisms contributing to the deficits in hippocampal synaptic plasticity in mice lacking amyloid precursor protein. Neuropharmacology 38: 349-359.

Selkoe DJ. 1991. The molecular pathology of Alzheimer's disease. Neuron 6: 487-498. 
Selkoe DJ. 2002. Alzheimer's disease is a synaptic failure. Science 298: 789-791.

Selkoe DJ. 2011. Resolving controversies on the path to Alzheimer's therapeutics. Nat Med 17: 1060-1065.

* Serrano-Pozo A, Frosch MP, Masliah E, Hyman BT. 2011. Neuropathological alterations in Alzheimer disease. Cold Spring Harb Pespect Med doi: 10.1101/cshperspect.a006189.

Serrano-Pozo A, William CM, Ferrer I, Uro-Coste E, Delisle MB, Maurage CA, Hock C, Nitsch RM, Masliah E, Growdon $\mathrm{JH}$, et al. 2010. Beneficial effect of human antiamyloid- $\beta$ active immunization on neurite morphology and tau pathology. Brain 133: 1312-1327.

Shankar GM, Bloodgood BL, Townsend M, Walsh DM, Selkoe DJ, Sabatini BL. 2007. Natural oligomers of the Alzheimer amyloid- $\beta$ protein induce reversible synapse loss by modulating an NMDA-type glutamate receptordependent signaling pathway. J Neurosci 27: 2866-2875.

Shankar GM, Li S, Mehta TH, Garcia-Munoz A, Shepardson NE, Smith I, Brett FM, Farrell MA, Rowan MJ, Lemere CA, et al. 2008. Amyloid- $\beta$ protein dimers isolated directly from Alzheimer's brains impair synaptic plasticity and memory. Nat Med 14: 837-842.

Shankar GM, Leissring MA, Adame A, Sun X, Spooner E, Masliah E, Selkoe DJ, Lemere CA, Walsh DM. 2009. Biochemical and immunohistochemical analysis of an Alzheimer's disease mouse model reveals the presence of multiple cerebral $A \beta$ assembly forms throughout life. Neurobiol Dis 36: 293-302.

Shipton OA, Leitz JR, Dworzak J, Acton CE, Tunbridge EM, Denk F, Dawson HN, Vitek MP, Wade-Martins R, Paulsen O, et al. 2011. Tau protein is required for amyloid $\{\beta\}$-induced impairment of hippocampal long-term potentiation. J Neurosci 31: 1688-1692.

Shoji M, Golde TE, Ghiso J, Cheung TT, Estus S, Shaffer LM, Cai X, McKay DM, Tintner R, Frangione B, et al. 1992. Production of the Alzheimer amyloid $\beta$ protein by normal proteolytic processing. Science 258: 126-129.

Simakova O, Arispe NJ. 2007. The cell-selective neurotoxicity of the Alzheimer's $A \beta$ peptide is determined by surface phosphatidylserine and cytosolic ATP levels. Membrane binding is required for $\mathrm{A} \beta$ toxicity. $J$ Neurosci 27: 13719-13729.

Snyder EM, Nong Y, Almeida CG, Paul S, Moran T, Choi EY, Nairn AC, Salter MW, Lombroso PJ, Gouras GK, et al. 2005a. Regulation of NMDA receptor trafficking by amyloid-B. Nat Neurosci 8: 1051-1058.

Spires-Jones TL, Meyer-Luehmann M, Osetek JD, Jones PB, Stern EA, Bacskai BJ, Hyman BT. 2007. Impaired spine stability underlies plaque-related spine loss in an Alzheimer's disease mouse model. Am J Pathol 171: 1304-1311.

Sun B, Halabisky B, Zhou Y, Palop JJ, Yu GQ, Mucke L, Gan L. 2009. Imbalance between GABAergic and glutamatergic transmissions impairs adult neurogenesis in an animal model of Alzheimer's disease. Cell Stem Cell 5: 624-633.

Supnet C, Bezprozvanny I. 2010. The dysregulation of intracellular calcium in Alzheimer disease. Cell Calcium 47: $183-189$.

Tackenberg C, Brandt R. 2009. Divergent pathways mediate spine alterations and cell death induced by amyloid- $\beta$, wildtype tau, and R406W tau. J Neurosci 29: 14439-14450.

Takahashi RH, Milner TA, Li F, Nam EE, Edgar MA, Yamaguchi H, Beal MF, Xu H, Greengard P, Gouras GK. 2002.
Intraneuronal Alzheimer a $\beta 42$ accumulates in multivesicular bodies and is associated with synaptic pathology. Am J Pathol 161: 1869-1879.

Takahashi RH, Almeida CG, Kearney PF, Yu F, Lin MT, Milner TA, Gouras GK. 2004. Oligomerization of Alzheimer's $\beta$-amyloid within processes and synapses of cultured neurons and brain. J Neurosci 24: 3592-3599.

Terry RD, Masliah E, Salmon DP, Butters N, DeTeresa R, Hill R, Hansen LA, Katzman R. 1991. Physical basis of cognitive alterations in Alzheimer's disease: Synapse loss is the major correlate of cognitive impairment. Ann Neurol 30: 572-580.

Verdier Y, Zarándi M, Penke B. 2004. Amyloid $\beta$-peptide interactions with neuronal and glial cell plasma membrane: Binding sites and implications for Alzheimer's disease. J Pept Sci 10: 229-248.

Vogt DL, Thomas D, Galvan V, Bredesen DE, Lamb BT, Pimplikar SW. 2009. Abnormal neuronal networks and seizure susceptibility in mice overexpressing the APP intracellular domain. Neurobiol Aging 32: 1725-1729.

Walsh DM, Lomakin A, Benedek GB, Maggio JE, Condron MM, Teplow DB. 1997. Amyloid b-protein fibrillogenesis: Detection of a protofibrillar intermediate. J Biol Chem 272: 22364-22374.

Walsh DM, Tseng BP, Rydel RE, Podlisny MB, Selkoe DJ. 2000. Detection of intracellular oligomers of amyloid $\beta$-protein in cells derived from human brain. Biochemistry 39: 10831-10839.

Walsh D, Klyubin I, Fadeeva J, William K. Cullen W, Anwyl R, Wolfe M, Rowan M, Selkoe D. 2002. Naturally secreted oligomers of the Alzheimer amyloid $\beta$-protein potently inhibit hippocampal long-term potentiation in vivo. Nature 416: 535-539.

Wang Q, Walsh DM, Rowan MJ, Selkoe DJ, Anwyl R. 2004. Block of long-term potentiation by naturally secreted and synthetic amyloid $\beta$-peptide in hippocampal slices is mediated via activation of the kinases c-Jun $\mathrm{N}$-terminal kinase, cyclin-dependent kinase 5, and pp38 mitogenactivated protein kinase as well as metabotropic glutamate receptor type 5. J Neurosci 24: 3370-3378.

Wei W, Nguyen LN, Kessels HW, Hagiwara H, Sisodia S, Malinow R. 2010. Amyloid $\beta$ from axons and dendrites reduces local spine number and plasticity. Nat Neurosci 13: $190-196$.

Winton MJ, Lee EB, Sun E, Wong MM, Leight S, Zhang B, Trojanowski JQ, Lee VM. 2011. Intraneuronal APP, not free $A \beta$ peptides in $3 \times T$ Tg-AD mice: Implications for tau versus $A \beta$-mediated Alzheimer neurodegeneration. J Neurosci 31: 7691-7699.

Yan SD, Roher A, Schmidt AM, Stern DM. 1999. Cellularcofactors for amyloid $\beta$-peptide-induced cell stress. Moving from cell culture to in vivo. Am J Pathol 155: 1403-1411.

Yang AJ, Chandswangbhuvana D, Margol L, Glabe CG. 1998. Loss of endosomal/lysosomal membrane impermeability is an early event in amyloid $A \beta 1-42$ pathogenesis. J Neurosci Res 52: 691-698.

Zempel H, Thies E, Mandelkow E, Mandelkow EM. 2010. A $\{\beta\}$ oligomers cause localized $\mathrm{Ca}^{2+}$ elevation, missorting of endogenous tau into dendrites, tau phosphorylation, and destruction of microtubules and spines. $J$ Neurosci 30: 11938-11950. 


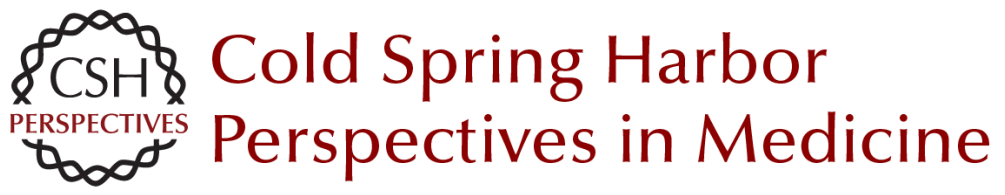

\section{Neurotoxicity of Amyloid $\beta$-Protein: Synaptic and Network Dysfunction}

Lennart Mucke and Dennis J. Selkoe

Cold Spring Harb Perspect Med 2012; doi: 10.1101/cshperspect.a006338 originally published online March 13, 2012

Subject Collection The Biology of Alzheimer Disease

Animal Models of Alzheimer Disease

Frank M. LaFerla and Kim N. Green

Neurovascular Dysfunction and Faulty Amyloid $\beta$

-Peptide Clearance in Alzheimer Disease Abhay P. Sagare, Robert D. Bell and Berislav V. Zlokovic

Treatment Strategies Targeting Amyloid $\beta$-Protein Dale Schenk, Guriqbal S. Basi and Menelas N. Pangalos

The Ubiquitin-Proteasome System and the Autophagic-Lysosomal System in Alzheimer Disease

Yasuo Ihara, Maho Morishima-Kawashima and Ralph Nixon

Neurotoxicity of Amyloid $\beta$-Protein: Synaptic and Network Dysfunction Lennart Mucke and Dennis J. Selkoe

Proteolytic Degradation of Amyloid $\beta$-Protein Takaomi Saido and Malcolm A. Leissring

Brain Imaging in Alzheimer Disease

Keith A. Johnson, Nick C. Fox, Reisa A. Sperling, et al.

Symptomatic and Nonamyloid/Tau Based Pharmacologic Treatment for Alzheimer Disease Paul S. Aisen, Jeffrey Cummings and Lon S. Schneider
Alzheimer Disease in 2020

David M. Holtzman, Eckhard Mandelkow and

Dennis J. Selkoe

The Genetics of Alzheimer Disease Rudolph E. Tanzi

Fluid Biomarkers in Alzheimer Disease Kaj Blennow, Henrik Zetterberg and Anne M. Fagan

Epidemiology of Alzheimer Disease Richard Mayeux and Yaakov Stern

Biochemistry and Cell Biology of Tau Protein in Neurofibrillary Degeneration

Eva-Maria Mandelkow and Eckhard Mandelkow

Biochemistry of Amyloid $\beta$-Protein and Amyloid Deposits in Alzheimer Disease

Colin L. Masters and Dennis J. Selkoe

The Neuropsychological Profile of Alzheimer

Disease

Sandra Weintraub, Alissa H. Wicklund and David P. Salmon

Apolipoprotein E and Apolipoprotein E Receptors: Normal Biology and Roles in Alzheimer Disease David M. Holtzman, Joachim Herz and Guojun Bu

For additional articles in this collection, see http://perspectivesinmedicine.cshlp.org/cgi/collection/ 